\title{
PESTICIDE RESIDUES IN THE WATER AND FISH (LAGOON TILAPIA) SAMPLES FROM LAGOONS IN GHANA
}

\author{
D.K. Essumang ${ }^{1 *}$, G.K. Togoh ${ }^{2}$ and L. Chokky ${ }^{3}$ \\ ${ }^{1}$ Department of Chemistry, University of Cape Coast, Ghana \\ ${ }^{2}$ Laboratory Technology Department, University of Cape Coast, Ghana \\ ${ }^{3}$ Environmental Sciences Department, University of Cape Coast, Ghana
}

(Received October 13, 2007; revised October 28, 2008)

\begin{abstract}
This study was to ascertain the presence and subsequent amount of four organochlorine pesticides: dichlorodiphenyl dichloroethylene (2,4'-DDE), 4,4'-dichlorodiphenyldichloroethane (4,4'-DDD), p,p'-dichlorodiphenyltrichloroethane [p,p'-DDT (r) (i) (f)] and Propiconazol (f); and four organophosphorous pesticides: Fenitrothion (i), Chlorpyrifos (i), Dichlorvos (a) (i) and Diazinon (a) (i) in Chemu lagoon (Tema), Korle lagoon (Accra), Fosu lagoon (Cape Coast) and the Etsii lagoon (Abandzi). Liquid-liquid and liquid-solid extraction technique was employed to extract pesticide residues in water and fish samples, respectively, using 1:1 (v/v) ethyl acetate/dichloromethane mixture before being analyzed by gas chromatography. The highest level of pesticide contaminations was recorded in the Chemu lagoon as compared to the Korle lagoon and Fosu lagoon, with the Etsii lagoon showing the least contamination. The total average pesticide residues in water samples from the four lagoons: Chemu, Korle, Fosu and Etsii are $2.6384 \mathrm{mg} / \mathrm{L}, 0.4992 \mathrm{mg} / \mathrm{L}, 0.3045 \mathrm{mg} / \mathrm{L}$ and $1.3629 \mathrm{mg} / \mathrm{L}$, respectively. The total average pesticide residues obtained in fish samples (Sarotherodon melaanothern) from the Fosu and Etsii lagoons are $0.0155 \mathrm{mg} / \mathrm{kg}$ and $0.0088 \mathrm{mg} / \mathrm{kg}$, respectively. This shows some level of exposure of pesticide which would be harmful to human.
\end{abstract}

KEY WORDS: Oraganochlorine, Organophosphorous, 2,4'-DDE, 4,4'-DDD, p,p'-DDT (r) (i) (f), Propiconazol (f), Fenitrothion (i), Chlorpyrifos (i), Dichlorvos (a) (i), Diazinon (a) (i), Chemu lagoon, Sarotherodon melaanothern

\section{INTRODUCTION}

In recent times, the extent of the use of pesticides, and their mode of application including their abuse especially in agriculture have been of much concern to environmental scientists. Alongside their uses are also the residual effect of these pesticides and particularly their replicating effect on human health [1].

Pesticide residue as used in this research work is the residual amount of active components of a particular pesticide or group of pesticides found in a commodity (that is food or water) after the pesticide has accomplished the primary purpose of its application; or the residual amount of a pesticide found in a product which has been in the area of the pesticide application.

Though pesticides are often misunderstood to refer only to insecticides, the term pesticide also applies to herbicides, fungicides, acaricides and other substances used to control pest. Under the US law, a pesticide may also refer to any substance or mixture of substances intended for use as a plant regulator, defoliant or desiccant [1].

The contamination of lagoons is a major source of concern since it is the habitat for fish and other aquatic organisms such as mussels, oysters, prawns and lobsters which are major sources of protein for most people in Ghana. An uncontrolled chemical activity in water bodies implies a high rate of exposure to humans who obtain much of their protein nutrition from these sources, and also to those who take in vegetable produced using such waters as means of irrigation. On the other hand, some amount of the chemicals used in the form of pesticides end up in the tissue of aquatic organisms and bio-accumulates with time [2].

*Corresponding author. E-mail: kofiessumang@yahoo.com 
The presence of pesticides in water (particularly bio-refactory organics that is aromatic chlorinated hydrocarbons) impacts objectionable and offensive taste, odours and colours to fish and aquatic plants even when they are present in low concentrations [3].

The organochlorine (OC) pesticides are among the major types of pesticides, notorious for their high toxicity, their persistence in the physical environment and their ability to enter the food chain [4]. Although the production and use of many types of OCs and organophosphorus (OPs) have been severely limited in many countries including Ghana, they are, nevertheless, still being used unofficially in large quantities in many parts of Ghana, and in other developing countries because of their effectiveness as pesticides and their relatively low cost $[5,6]$.

The OCs, unlike the OPs pesticides are much more resistant to microbial degradation and have a propensity to concentrate in lipid rich tissues of aquatic organisms and most mammals. These properties lead directly to their most undesirable characteristics - the environmental persistence, bio-concentration, and bio-magnification through the food chain.

Unlike the OPs - Dichlorvos, Diazinon, Chlorpyrifos and Fenitrothion - which are readily deactivated and degraded by micro-organisms and therefore do not readily accumulate, the OCs residues are detectable in most surface water bodies and are bioconcentrated in shellfish and other biota in these ecosystems [7]. A gas-chromatogram of extracts from some sediments reveal the presence of dichlorodiphenyl dichloroethylene (2,4'-DDE), 4,4'- dichlorodiphenyldichloroethane (4,4'-DDD), p,p'-dichlorodiphenyltrichloroethane [p,p'-DDT(r)(i)(f)] and dieldrin each in the range of $0.002-0.02 \mathrm{mg} / \mathrm{L}$. However, the concentration of these pesticides in organisms dwelling in these sediments is 10-20 times higher [8].

This work determined the concentration of organophosphorus (OP) and organochlorine (OC) pesticides that has been used extensively in Ghana. The OC and OP pesticides have been used in Ghana for more than forty years, both for agricultural and public health purposes. Though it has been banned internationally, it is still being used in Ghana, hence, the need for its continual monitoring.

The OC of interest are 2,4-DDE, 4,4-DDT, 2,4-DDD and Propiconazol. The OP of interest are Dichorvos, Diazinon, Chlorpyrifos and Fenitrothion.

\section{EXPERIMENTAL}

The sampling sites involve areas in Ghana where most industries are situated. The lagoons in this area are Chemu lagoon in Tema, Korle lagoon in Accra, Fosu lagoon in Cape Coast (classified as heavily polluted), and Etsii lagoon at Abandzie near Cape Coast (classified in Ghana as less polluted). Some of these lagoons still serve as a source of fish production in Ghana. The sampling sites are shown in Figure 1.

Sampling and sample handling

Water samples. Approximately $2.5 \mathrm{~L}$ water samples were collected in duplicates at four different times into Winchester bottles - previously cleaned with a detergent and rinsed with water followed by ethyl acetate and then dried-from the midstream of Chemu, Korle, Fosu and Etsii lagoons in Tema, Accra, Cape Coast and Abandze, respectively. The water samples were immediately transported to the laboratory in an ice chest with ice and stored at $4{ }^{\circ} \mathrm{C}$ in a refrigerator for two days before extraction and analysis. The water samples were obtained from two source points in each of the lagoons (where effluents enters the lagoon).

Fish samples. Approximately $500 \mathrm{~g}$ of each of the fish samples (Sarotherodon melaanothern) were also obtained from the Fosu and Etsii lagoons and put into an ice chest. There were no fish 
species in the Chemu and Korle lagoons due to excessive pollution. The fish samples were immediately transported to the laboratory in an ice chest with ice and stored at $4{ }^{\circ} \mathrm{C}$ in a refrigerator for two days before extraction and analysis. The fish samples were obtained in a composite manner and placed in clean wide-mouth glassy containers and covered immediately after sampling.

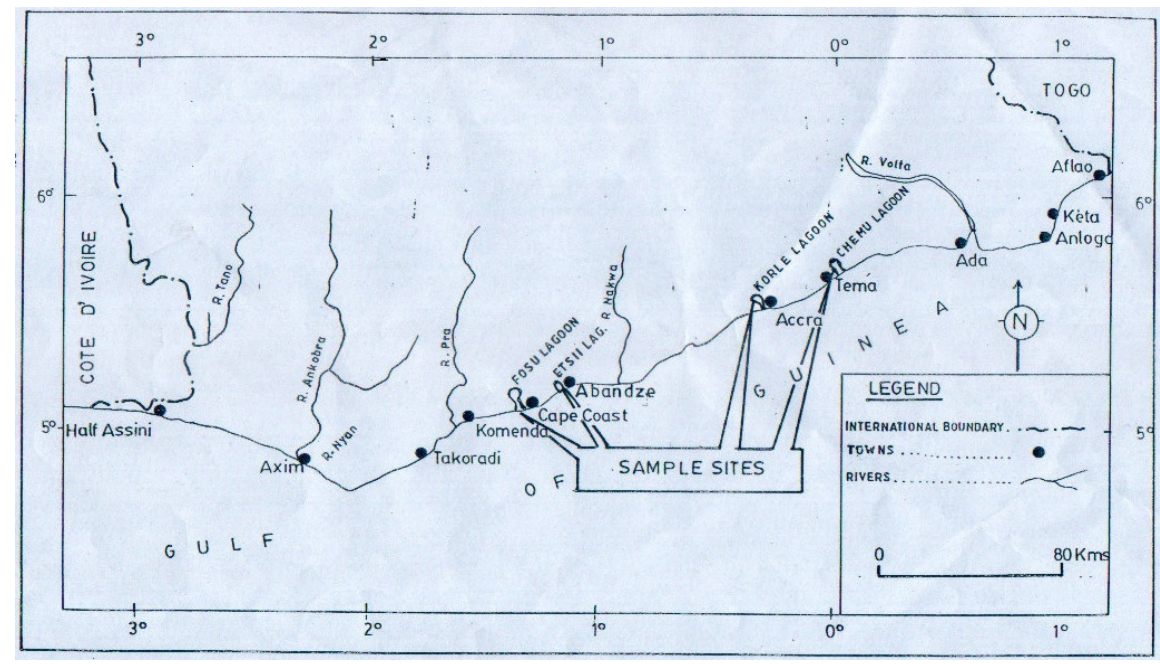

Figure 1. Map of Southern Ghana showing the sampling sites.

\section{Equipment and reagents}

The gas chromatograph used for the pesticide residue analysis was Varian CP-3800 series equipped with the ${ }^{63} \mathrm{Ni}$ selective electron capture detector and phosphorus detector. The GC column employed was capillary column, GS-Q (30 m x $0.53 \mathrm{~mm}$ i. d.), J \& W Scientific, CA, USA for organochlorine and organophosphorous pesticides. Rotary vacuum evaporator (BUCHI type R-210/R-215, Switzerland), Hamilton Beach Commercial Blender (USA), a Libror EB3200s (Japan) weighing balance with capacity of $3200 \mathrm{~g}$ and a BUCHI water bath, B-480/B-485 (Switzerland).

Solvents used were ethyl acetate, dichloromethane, acetonitrile, and hexane. The following were also used anhydrous sodium sulphates, silica gel and sodium hydrogen carbonate. All the reagents were of analytical (HPLC) grade supplied by BDH, London, UK.

\section{Extraction of pesticides from lagoon water}

The extraction technique employed in this work was the US EPA Method 3510 [9] for aqueous matrix for the analysis of semi-volatile and non-volatile organics. The extracts were cleaned up by using the US EPA Method 3620B [10].

$500 \mathrm{~mL}$ of the aqueous sample was measured and transferred into a $1000 \mathrm{~mL}$ separatory funnel. The aqueous sample was extracted three times with portions $100 \mathrm{~mL}$ of $1: 1(\mathrm{v} / \mathrm{v})$ ethyl acetate/dichloromethane mixture. The separatory funnel was clapped for $30 \mathrm{~min}$ to allow phase separation. The combined organic phases were collected into a $500 \mathrm{~mL}$ beaker with the aqueous 
phase discarded. The combined organic layer was then dried of any aqueous substance with $20 \mathrm{~g}$ of anhydrous sodium sulfate and allowed to settle.

The organic content was then decanted into a $300 \mathrm{~mL}$ round bottom flask and the content evaporated to dryness using the rotary evaporator at $40{ }^{\circ} \mathrm{C}$. The pesticide in the rotary flask was then dissolved and collected with $2 \mathrm{~mL}$ of ethyl acetate and transferred into a $2 \mathrm{~mL}$ vial ready for a clean-up.

\section{Extraction of pesticides from fish samples}

$20 \mathrm{~g}$ of macerated fresh fish sample ( $S$. melaanothern) was weighed into a $150 \mathrm{~mL}$ conical flask followed by the addition of $20 \mathrm{~g}$ and $5 \mathrm{~g}$ of anhydrous sodium sulfate and sodium hydrogen carbonate, respectively. $100 \mathrm{~mL}$ of $1: 1(\mathrm{v} / \mathrm{v})$ ethyl acetate/dichloromethane mixture was transferred into the $20 \mathrm{~g}$ of macerated fish samples and thoroughly mixed by shaking the conical flask while corked. $20 \mathrm{~g}$ of anhydrous sodium sulfate was then added to the content of the conical flask followed by $20 \mathrm{~g}$ of sodium hydrogen carbonate. The conical flask was corked tightly and the mixture shaken thoroughly for $10 \mathrm{~min}$. The content was then allowed to stand for $3 \mathrm{~h}$. The organic layer was then decanted into a $200 \mathrm{~mL}$ round bottom flask and evaporated using the rotary evaporator at $40{ }^{\circ} \mathrm{C}$. The pesticide in the rotary flask was then dissolved and collected with $2 \mathrm{~mL}$ of ethyl acetate and transferred into a $2 \mathrm{~mL}$ vial and ready for the clean-up.

Silica gel clean-up of sample extracts (USEPA Method 3620B) [10]

$10 \mathrm{~g}$ portion of deactivated silica gel was weighed and transferred into a $10 \mathrm{~mm}$ i.d. glass chromatographic column followed by the addition of $3 \mathrm{~g}$ of anhydrous sodium sulfate. $10 \mathrm{~mL}$ of the $1: 1(\mathrm{v} / \mathrm{v})$ ethyl acetate/dichloromethane mixture was used to wet and rinse the column.

The extract residue (water and fish) in $2 \mathrm{~mL}$ ethyl acetate was then transferred into the column and the extract vial rinsed (three times) with $2 \mathrm{~mL}$ ethyl acetate and added to the column. The column was then eluted with $80 \mathrm{~mL}$ portion of ethyl acetate/dichloromethane at a rate of $5 \mathrm{~mL} / \mathrm{min}$ into a conical flask as fraction one. The column was eluted again with $50 \mathrm{~mL}$ portion of ethyl acetate/dichloromethane for the second elution and added to the first extract [10].

All the fractions of each sample were concentrated to dryness using a rotary evaporator at 40 ${ }^{\circ} \mathrm{C}$. Each residue was then dissolved and collected in $2 \mathrm{~mL}$ ethyl acetate for gas chromatograph analysis.

\section{De-fattening of the fish sample extracts}

$50 \mathrm{~mL}$ of $1: 1(\mathrm{v} / \mathrm{v})$ hexane/acetonitrile solution was added to the $2 \mathrm{~mL}$ pesticide extracted from the fish samples (S. melaanothern) in a $100 \mathrm{~mL}$ separatory funnel. The separatory funnel was shaken gently for $3 \mathrm{~min}$ while releasing the gas pressure. The separatory funnel was then allowed to stand for $20 \mathrm{~min}$ to allow for phase separation of the organic solvents.

The acetonitrile fraction containing the pesticide was collected into a $50 \mathrm{~mL}$ beaker while the fat containing hexane solvent phase was discarded. The acetonitrile solvent extract obtained was further cleaned-up using $25 \mathrm{~mL}$ of the pure hexane. The acetonitrile fraction was then concentrated with rotary evaporator at $40{ }^{\circ} \mathrm{C}$ and the content of the flask dissolved and collected with $2 \mathrm{~mL}$ of ethyl acetate into a $2 \mathrm{~mL}$ vial.

The vial containing the pesticide extract was then stored in the refrigerator at $4{ }^{\circ} \mathrm{C}$ for subsequent qualitative and quantitative analysis using GC. 


\section{Method validity}

The recovery analysis and the validation of the extraction method were carried out at a fortification level of $0.5 \mathrm{mg} / \mathrm{kg}$ by introducing $25 \mathrm{~mL}$ of a mixed standard pesticide solution containing $25 \mu \mathrm{g} / \mathrm{L}$ of dichlorodiphenyl dichloroethylene (2,4'-DDE), 4,4'-dichlorodiphenyldichloroethane (4,4'-DDD), p,p'-dichlorodiphenyltrichloroethane [p,p'-DDT(r)(i)(f)] $100 \mathrm{~mL}$ of distilled water was measured out into a $100 \mathrm{~mL}$ measuring cylinder and transferred into a 300 $\mathrm{mL}$ separatory funnel. $25 \mathrm{~mL}$ of a $2 \mathrm{mg} / \mathrm{kg}$ mix standard pesticide solution was introduced into the funnel containing the distilled water and then swirled gently. The pesticides in the water were then extracted with two portions of $100 \mathrm{~mL}$ of 1:1 (v/v) ethyl acetate/dichloromethane solution. The extract obtained - placed in a $200 \mathrm{~mL}$ round bottom flask - was then cleaned using a silica gel clean-up and then reduced to near dryness using a rotary evaporator at $40{ }^{\circ} \mathrm{C}$. Solvent exchanged was carried out by dissolving and collected the content with $2 \mathrm{~mL}$ of ethyl acetate and then transferred into a $2 \mathrm{~mL}$ vial for subsequent analysis.

These analyses were carried out at the Pesticide Residue Laboratory of the Ghana Standards Board.

\section{RESULTS AND DISCUSSION}

The validation analysis gave an average of $65 \%$ extraction efficiency and an average reproducibility of $93 \%$ indicating that the analytical process was efficient.

The results of this study indicate the presence of organochlorine (OC) and organophosphorus (OP) pesticides in Etsii, Fosu, Korle and Chemu lagoons to varying degrees. This also gives a clear trend of the extent of chemical contamination in these four lagoons. A general trend from the results indicates an increase in pesticides residue levels in the lagoon water as one move from Etsii, Fosu, and Korle and to Chemu lagoon for both OCs and OPs as illustrated in Tables 1 and 2. These pesticides and their derivatives have been banned in most parts of the world; however, the results of the study have shown that they are still being used in Ghana.

Higher values are realized for the OCs than the OPs with respect to each water sample and the individual lagoons as shown in Tables 1 and 2. This is because OC pesticides such as DDT (and its metabolites DDE and DDD) and Propiconazol are resistant to microbial and photolytic degradation, and are therefore persistent in the environment (soils and water) where they are applied, while the OPs are readily deacitivated and degraded by microbial activities.

Table 1. Average residue levels of organochlorine pesticides in water samples.

\begin{tabular}{|l|c|c|c|c|}
\hline Samples from the various lagoons & \multicolumn{4}{|c|}{ Mean concentration in mg/L } \\
\hline & $2,4^{\prime} \mathrm{DDE}$ & $4,4^{\prime} \mathrm{DDD}$ & p-p' DDT & Propiconazol \\
\hline EML & $0.0193 \pm 0.0002$ & $0.0169 \pm 0.0010$ & $0.0194 \pm 0.0010$ & $1.2877 \pm 0.0090$ \\
\hline KLM & $0.4844 \pm 0.0067$ & ND & ND & ND \\
\hline FLM & $0.0361 \pm 0.0043$ & $0.0058 \pm 0.0009$ & $0.0202 \pm 0.0020$ & $0.1794 \pm 0.0096$ \\
\hline CHW & $0.0718 \pm 0.0009$ & $0.0369 \pm 0.0007$ & $0.0360 \pm 0.0009$ & $0.5164 \pm 0.0100$ \\
\hline MRL (ADI) [11] & 0.0200 & 0.0200 & 0.0200 & 0.1000 \\
\hline
\end{tabular}

ELW: Etsii Lagoon water sample, FLW: Fosu Lagoon water sample, CHW: Chemu Lagoon water sample, KLW: Korle Lagoon water sample. 
Table 2. Average residue levels of organophosphorous pesticides in water samples.

\begin{tabular}{|l|c|c|c|c|}
\hline $\begin{array}{l}\text { Samples from the various } \\
\text { lagoons }\end{array}$ & \multicolumn{4}{|c|}{ Mean concentration in mg/L } \\
\hline & Dichlorvos & Diazinon & Chlorpyrifos & Fenitrothion \\
\hline EML & ND & ND & $0.0183 \pm 0.0022$ & $0.0013 \pm 0.0031$ \\
\hline KLM & $0.0033 \pm 0.0006$ & $0.0013 \pm 0.0004$ & $0.0062 \pm 0.0020$ & ND \\
\hline FLM & ND & ND & ND & $0.0148 \pm 0.0023$ \\
\hline CHW & $0.0039 \pm 0.0007$ & $0.1855 \pm 0.005$ & $1.5451 \pm 0.0399$ & $0.2428 \pm 0.0100$ \\
\hline MRL (ADI) [12] & 0.0040 & 0.0020 & 0.0100 & 0.0030 \\
\hline
\end{tabular}

ELW: Abandzi Lagoon water sample, FLW: Fosu Lagoon water sample, CHW: Chemu Lagoon water sample,

KLW: Korle Lagoon water sample.

Pesticide residues in the lagoon water

However, the higher value of $0.4844 \mathrm{mg} / \mathrm{L}$ realized for 2,4'-DDE in Table 1 for Korle water samples indicated that there is a higher concentration of the metabolites of DDT in the water although DDT itself may be in a lower concentration or might not be in use in this particular lagoon as compared with the standard $0.020 \mathrm{mg} / \mathrm{L}$. The persistence of these metabolites may find their residence in the soil sediments as in peculiar in most water bodies. The high value of $1.29 \mathrm{mg} / \mathrm{L}$ compared to the standard $0.1000 \mathrm{mg} / \mathrm{L}$ obtained for Propiconazol in Etsii lagoon also indicates that this particular pesticide might be in extensive use in the environs of the lagoon and are drifted by air current or introduced into the lagoon as a result of run offs. This is because the Etsii lagoon is relatively clean in appearance by physical inspection and for the fact that there is no industrial activity taking place in its immediate environment except for some farming which might have contributed to the high level.

A value of $0.0183 \mathrm{mg} / \mathrm{L}$ was realized for Chlorpyrifos in Etsii lagoon than in Fosu lagoon, Dichlorvos and Diazinon were not detected in its samples showing a relatively lower level of chemical contamination in the Etsii lagoon. However, Korle lagoon recorded a value of 0.0148 $\mathrm{mg} / \mathrm{L}$ for Fenitrothion, although Dichlorvos, Diazinon and Chlorpyrifos were not detected in it.

Two of the lagoons under study are located within the major industrial areas in Ghana. Accra and Tema where Korle and Chemu lagoons are located, respectively, are the major industrial cities in Ghana and therefore, the presence of the pesticides indicates industrial pollution. The Fosu Lagoon in Cape Coast is also heavily polluted. This is so because the lagoon receives effluent directly from a regional hospital, two boarding schools and a garage. The organophosphosrous pesticides residue levels (nd-1.5451) $\mathrm{mg} / \mathrm{L}$ as indicated in Table 2 for the individual lagoons were far higher than the range of $0.009-0.523 \mathrm{mg} / \mathrm{L}$ that was obtained by Ntow [5] in the Volta Lake. This is also an indication of possible pesticides misuse in the marine environment.

Although the total pesticide residue levels in the individual lagoons - Etsii, Fosu Korle and Chemu - each is less than $4 \mathrm{mg} / \mathrm{L}$ (Table 3) and considered by Biney [13] as unpolluted, the values obtained for pesticides residues are high enough to pose a risk to the health of organisms, mammal and humans who obtain their nutrition from them [11, 12]. The problems posed by these pesticides become an issue as they may bio-accumulate in the bodies of aquatic organisms that dwell in them and the effect of these pesticides magnifies higher up the food chain.

The general trend in the concentration of the pesticides residues in the water samples from the four lagoons recorded higher concentration values for Chemu lagoon, followed by Fosu lagoon, the Korle lagoon and then Etsii lagoon. The resultant total pesticide residue levels in the four lagoons recorded a trend showing the highest concentration of residues in the Chemu lagoon, followed by Etsii lagoon and then Korle lagoon and Fosu lagoon with their concentration values being $2.6334 \mathrm{mg} / \mathrm{L}, 1.3629 \mathrm{mg} / \mathrm{L}, 0.4992 \mathrm{mg} / \mathrm{L}$ and $0.3045 \mathrm{mg} / \mathrm{L}$, 
respectively. The Chemu lagoon is located in a place where about $40 \%$ of Ghana's industry activities are located. The high levels obtained for the pesticide residues indicate heavy industrial pollution of the marine environment and every effort must be made for its reversal

Table 3. Total pesticides residues in the water samples from the three lagoons.

\begin{tabular}{|l|c|c|c|}
\hline Samples from the various lagoons & \multicolumn{3}{|c|}{ Mean concentration in mg/L } \\
\hline & Organochlorine & Organophosphorous & Total pesticides \\
\hline EML & 1.3433 & 0.0196 & 1.3629 \\
\hline KLM & 0.4844 & 0.0148 & 0.4992 \\
\hline FLM & 0.2937 & 0.0108 & 0.3045 \\
\hline CHW & 0.6611 & 1.9773 & 2.6384 \\
\hline
\end{tabular}

ELW: Etsii Lagoon water sample, FLW: Fosu Lagoon water sample, CHW: Chemu Lagoon water sample, KLW: Korle Lagoon water sample.

Pesticides residues in fish (S. melaanothern)

Pesticide residue levels obtained in the fish samples from Etsii and Fosu lagoons were all less than those from their corresponding water samples. All the organochlorine pesticides analyzed in the fish samples in both lagoons were detected, however, Dichlorvos and Fenitrothion organophosphorous pesticides were not detected (Tables 4 and 5). All the pesticides present in the fish samples were below the Maximum Residue Limits (MRL) of between 0.0030-0.1000 $\mathrm{mg} / \mathrm{kg}[11,12]$.

Table 3. Average residue levels of organochlorine pesticides in fish samples.

\begin{tabular}{|l|c|c|c|c|}
\hline Samples from the various lagoons & \multicolumn{4}{|c|}{ Mean concentration in mg/kg } \\
\hline & 2,4-DDE & 4,4-DDD & p,p-DDT & Propiconazol \\
\hline ELF & ND & $0.0001 \pm 0.00002$ & $0.0001 \pm 0.00002$ & $0.0072 \pm 0.0006$ \\
\hline FLF & ND & $0.0001 \pm 0.00002$ & $0.0003 \pm 0.00003$ & $0.0098 \pm 0.0005$ \\
\hline MRL (ADI) [1] & 0.0200 & 0.0200 & 0.0200 & 0.1000 \\
\hline
\end{tabular}

ELF: Etsii Lagoon fish sample, FLF: Fosu Lagoon fish sample.

Table 4. Average residue levels of organophosphorous pesticides in fish samples.

\begin{tabular}{|l|c|c|c|c|}
\hline Samples from the various lagoons & \multicolumn{4}{|c|}{ Mean concentration in mg/kg } \\
\hline & Dichlorvos & Diazinon & Chlorpyrifos & Fenitrothion \\
\hline ELF & ND & $0.0001 \pm 0.00001$ & $0.0001 \pm 0.00002$ & ND \\
\hline FLF & ND & $0.0001 \pm 0.00001$ & $0.0003 \pm 0.00003$ & ND \\
\hline MRL (ADI) [12] & 0.004 & 0.0020 & 0.0100 & 0.0030 \\
\hline
\end{tabular}

ELF: Etsii Lagoon fish sample, FLF: Fosu Lagoon fish sample.

Also, the total pesticide residues were higher in fish samples from the Fosu lagoon $(0.0155$ $\mathrm{mg} / \mathrm{kg}$ ) than that which was in the fish samples obtained from Etsii lagoon $(0.0088 \mathrm{mg} / \mathrm{kg})$. These are statistically different. The ratio of the total pesticides of Fosu lagoon to Etsii lagoon is about 2:1 (63.8:36.2 \%), respectively (Table 6). The higher value of pesticide residue in the Fosu lagoon fish sample is as result of the higher pollution level in that lagoon and, therefore, leading to a higher bio-accumulation of pesticides in the fish samples. However, all the pesticide residue levels were below the MRL values [11, 12] 
Table 6. Total pesticides residues in the fish samples from the lagoons in Ghana.

\begin{tabular}{|l|c|c|c|}
\hline Samples from the various lagoons & \multicolumn{3}{|c|}{ Mean concentration in mg/kg } \\
\hline & Organochlorine & Organophosphorous & Total pesticides \\
\hline ELF & 0.0086 & 0.0002 & 0.0088 \\
\hline FLF & 0.0151 & 0.0004 & 0.0155 \\
\hline Chemu ${ }^{*}$ & - & - & - \\
\hline Korle $^{*}$ & - & - & - \\
\hline
\end{tabular}

Chemu*: No fish sample was obtained from the Chemu Lagoon because it is heavily contaminated with industrial effluent from the Tema municipality. This has made the lagoon virtually dead to habitation by aquatic organism [14]. Korle*: This lagoon also didn't have any fish in it at the time of sampling because it has been dredge quite recently to improve its water quality and allow for its proper management [14].

Although there is no data on Ghana stating the safe maximum levels or limits of all the pesticides analysed in water and fish samples from the lagoons, their presence in the lagoons indicate a scope of environmental contamination and the extent of pollution of these surface water bodies.

Table 7 gives the statistics of the officially accepted pesticides in Ghana. However, this does not take care of those used un-officially.

Table 7. Pesticide imports into Ghana by WHO classification (1995 to 2000) [15].

\begin{tabular}{|l|l|l|l|}
\hline Hazardous class & Quantity (MT) & Percent \\
\hline I A & Extremely hazardous & 34 & 0.7 \\
\hline I B & Highly hazardous & 555 & 11.4 \\
\hline II & Moderately hazardous & 3,040 & 62.2 \\
\hline III & Slightly hazardous & 966 & 19.8 \\
\hline IV & Unlikely hazardous & 284 & 5.8 \\
\hline Total & & 4,884 & 100.0 \\
\hline
\end{tabular}

\section{CONCLUSIONS}

The pesticide residue analysis of the water samples from all the four lagoons recorded varying values indicating the presence of organochlorine (OCs) and organophosphorous (OPs) pesticides residues in these lagoons. These are 2,4-DDE, 4,4-DDD, p,p-DDT and Propiconazol, and Dichlorvos, Diazinon, Chlorpyrifos and Fenitrothion.

The fish sample analysed from the Etsii and Fosu lagoons showed the presence of all the OCs of interest but of lesser concentration than those of the water samples analysed from the same lagoons. However, Dichlorvos and Fenitrothion were not detected in the fish samples from both lagoons for the OPs pesticides residue analysis.

Among the OCs analysed, Propiconazol was in a higher concentration for both the water and fish samples followed by 2,4-DDE which is a metabolite of DDT. Among the OPs analysed, Chlorpyrifos was in a higher concentration followed by Diazinon-both of which are widely used as agricultural insecticides and also has many uses in households for pest control.

The total pesticide residues for the fish samples analysed, however, showed a higher bioaccumulation of pesticides in those of the Fosu lagoon than Etsii lagoon. The total pesticide residue concentrations are $0.0155 \mathrm{mg} / \mathrm{kg}$ and $0.0088 \mathrm{mg} / \mathrm{kg}$, respectively.

Consumption of fish and other aquatic products from these lagoons is most likely to pose some health risk to animals and humans who might obtain nutrition from them. Hence there is a need for vigorous education to preserve the water bodies. 


\section{AKNOWLEDGEMENTS}

The authors would like to express their profound gratitude to Mr. Samuel Frimpong (Assistant Scientific Officer at the Pesticide Residue Laboratory of the Ghana Standards Board) for his assistance in carrying out the various analyses. We would like to thank the government of Ghana for financial assistance.

\section{REFERENCES}

1. Hurst, P.; Alistair, H.; Nigel, D. The Pesticide Handbook, Journeyman Press: London; 1991.

2. Jiries, A.B.; Al Nasir, F.M.; Beese, F. Water, Air Soil Pollut. 2002, 133, 97.

3. De, A.K. Environmental Chemistry, 5th ed., New Age International Limited: New Dehli; 2003; p 192.

4. Ntow, W.J. Arch. Environ. Contam. Toxicol. 2001, 40, 557.

5. Ntow, W.J., Gijzen, H.J., Kelderman, P.; Drechsel, P. Pest. Manage. Sci. 2006, 62, 356.

6. Racke, K.D.; Skidmore, M.W.; Hamilton, D.J.; Unsworth, J.B.; Miyamoto, J.; Cohen, S.Z. Pure Appl. Chem. 1997, 69, 1349.

7. Holland, P.T.; Hickey, C.W.; Roper, D.S.; Trower, T.M. Arch. Environ. Contam. Toxicol. 1993, 25, 456.

8. Hickey, C.W.; Roper, D.S.; Holland, P.T.; Trower, T.M. Arch. Environ. Contam. Toxicol. 1995, 29, 221.

9. US-EPA Drinking Water Standards and Health Advisories, Washington, D.C: U.S. Environmental Protection Agency, Office of Water. EPA822R04005; 2004.

10. US-EPA Evaluation of Sample Extract Cleanup Using Solid-Phase Extraction Cartridges, Project Report, December 1989.

11. US-EPA Guidance for the Registration of Pesticide Product Containing Chlorobenzilate as the Active Ingredient, Washington DC; 1983.

12. US-EPA Memorandum from the office of Pesticides and Toxic Substances to Office of Pesticide Programs Division Director, Washington DC, 1991.

13. Biney, C. Oceanol. Acta 4 Suppl. (Special Volume) 1982, 39.

14. Boateng J.Y. Enhancing Business Community Relations Tema Oil Refinery Case Study, 2003. http://www.worldvolunteerweb.org/fileadmin/docs/old/pdf/2003/031201_EBCR_GH A_temaoil.pdf Accessed on the 23/10/2008.

15. Gerken, A; Suglo, J.; Braun, M. An Economic and Institutional Analysis of Current Practice and Factors Influencing Pesticide Use, A Publication of the Pesticide Policy Project, Hannover, 2001. This can also be found at www.ifgb.unihannover.de/fileadmin/EUE_files/PPP_Publicat/Series/PPP10.pdf This was accessed on 23/10/2008. 